\title{
THE IMPACT OF COST-BENEFIT ANALYSIS ON DECISION MAKING CONCERNING THE DEVELOPMENT OF THE URBAN TRANSPORT SYSTEM: CASE OF KAUNAS CITY
}

\author{
Vytautas DUMBLIAUSKAS, Vytautas GRIGONIS*, Andrius BARAUSKAS \\ Dept of Roads, Vilnius Gediminas Technical University, Lithuania
}

Received 11 May 2016; revised 9 September 2016; accepted 4 February 2017

\begin{abstract}
The formulation of scenarios for developing the urban transport infrastructure requires decisions mainly based on the intuition of experts in transport and highly influenced by public interest groups, business entities and political opinions. However, the reached decisions sometimes fail to be the most efficient. Therefore, to avoid errors and ensure the development of a sustainable transport system, the economical appraisal of infrastructure development scenarios is necessary. The economic evaluation of the developed scenarios can be carried out through macro-simulation and cost-benefit analysis. This paper deals with the Kaunas City Master Plan providing solutions to transport infrastructure development. According to the Master Plan, solutions can be classified considering 3 cathegories (priorities), although the detailed sequence of implementation is not given. With the help of macro-simulation, this study arranged Master Plan solutions into scenarios, checked all 20 scenarious and established an implementation order based on the theory of cost benefit analysis. The identified order substantially differs from the priorities set in the Master Plan.
\end{abstract}

Keywords: sustainable transport system, economic evaluation of scenarios, macro-simulation, master plan.

\section{Introduction}

Recently, sustainable development has become a fundamental component of transport system planning and policy-making (Haque et al. 2013). A generally accepted goal of planning a sustainable transport system is to achieve the above introduced system met economic, social and environmental protection needs thus simultaneously ensuring as minimum negative effects on the same three elements as possible. The sustainable transport system should be planned wisely in order to create a high-level transport infrastructure at a reasonable price and to ensure the lowest possible negative impact on the environment providing equal opportunities for travelling.

Sustainable development in urban areas has become more complex due to the zones intertwining with numerous recently emerged obstacles (Hassan, Lee 2015a), including intense urban sprawl, traffic congestion, transport problems, greenhouse gas emissions and social segregation (Hassan, Lee 2015b). Our behaviour addressed towards these issues presents another problem. For designing sustainable development strategies, researchers highly relay on engineering solutions (Martos et al. 2016) taking into account feedback from citizens, which leaves a smaller gap between both academic and decision making stakeholders and population (Martos et al. 2016; Barfod et al. 2011). In addition, planners need to be more critical of their own tacit knowledge and turn more actively to research-based knowledge. Researchers need to produce the knowledge planners need in ways that are useful and usable for them (Tennøy et al. 2016).

Consistent calls for urban planning can be more effectively integrated with transport investments and used for reducing travelling by personal motorized transport systems (Hickman et al. 2013). Taking into account that transport is priority for cities, the development of participatory, accountable and effective governance to support rapid and equitable urban transformation is a fundamental issue (Santos, Ribeiro 2015). Planners are trying to integrate complexity into master plans thus making them a long time expression of public intentions for urban places. However, master plans frequently become the victims of their own merits such as "comprehensiveness" in the approach and the so-called "rationality" in the interpretation of public interests (Kim, Rowe 2013).

*Corresponding author. E-mails: vytautas.grigonis@vgtu.lt,vytautas.grigonis@gmail.com 
The present urban transport systems face a number of problems that primarily are handled at the strategic level, e.g. through the elaboration of plans for transport system development. The prepared plans provide specific scenarios for developing transport networks. Each scenario needs to be assessed according to certain methods in order to estimate its possible performance (TRB 2010). Based on their performance, scenarios are prioritized working towards a goal of determining the sequence of implementing them and ensuring the rational allocation of available resources.

Assessing scenarios for transport system development can be accomplished using a variety of methods such as economic (for example traditional cost-benefit) analysis, multi-criteria analysis or a combination of both.

Multi-criteria analysis is an acknowledged technique for assessing sustainability at the neighbourhood level. Cost-benefit analysis is mainly used for infrastructure and large transformation projects (Beria et al. 2012; Grigonis et al. 2014; Grigonis, Paliulis 2007; Gühnemann et al. 2012).

Some papers (Kumarage, Weerawardana 2013; Beria et al. 2012; Hüging et al. 2014) illustrate mixed approaches integrating cost-benefit, and multi-criteria analyses are proposed in order to take into account quantitative indicators and justify sustainable (innovative) mobility measures that do not generate direct monetary benefit.

Nevertheless, economic analysis is the most common technique applied in Europe and worldwide. For example, cost-benefit analysis is the main or dominant evaluation method of transport investment projects in Denmark, Greece, Ireland, Portugal, Spain, Germany, Italy and Great Britain, whereas France, Belgium, the Netherlands and Austria highly rely on multi-criteria analysis (Griškevičiūtè-Gečienè 2010).

Unfortunately, priorities are often identified on the basis of intuition or the needs prevailing at the political level in Lithuania. For that reason, analytical assessment methods still hardly find their place. In the course of economic analysis, simulating transport systems is becoming an important part of transport system planning that ensures an objective and timely assessment of the proposed network development. Still, macro-simulation is seldom used for developing transport networks in Lithuania, even though this is required by regulatory documents. The organizers of spatial planning and municipalities approving the prepared documents should oblige planners to carry out analytical analysis (simulation) of future transport networks and provide justification for the planned scenarios.

The detailed economic evaluation requires life cycle analysis encompassing the prediction of many variables such as road deterioration, roadwork effects, Vehicle Operating Costs (VOCs), accident costs and time expenses (Kerali 2003). At the strategic level, this is hard to implement due to lack of data and high uncertainty about the future. Hence, this paper presents the simplified methodology and approach that estimates construction costs and benefits gained within the first year savings of travel time and VOCs. Other variables such as maintenance, operational cost are not taken into account in this study, however, these variables must be considered in the later stages of planning and design. It should be also noted that simulation results and summarized suggestions are useful for solving the problems of urban development and preparing comprehensive or special transport plans for the largest cities in Lithuania and Baltic countries.

Cost-effective scenarios for transport system development appear as a prerequisite for ensuring sustainable development, and therefore Lithuania requires a new approach to planning methodology that, all in all, should be quite simple, feasible and applied in urban development processes. Therefore, the article is aimed at developing simple methodology for selecting priority scenarious and undertaking demonstrational analysis focused on the specific street infrastructure development in Kaunas City. Thus, to achieve the goals of this work, the following tasks have been formulated:

- the construction of a four-stage model for a personal motorized transport system;

- development and description of scenarious;

- selecting quantitative criteria having an impact on the priority of scenario; assessing and ranking quantitative criteria and determining priority of the scenario;

- preparing a priority list for the implementation of scenarious.

\section{General information about the analysis framework and the model}

Kaunas is the second city in Lithuania considering population. The city is located in the central part of the country at the confluence of the Nemunas and Neris rivers. The area of Kaunas City covers $158 \mathrm{~km}^{2}$. Kaunas is home to about 297 thousand inhabitants using the $900 \mathrm{~km}$ long transport network.

According to the conducted survey (Kauno miesto savivaldybe 2014), about $60 \%$ of Kaunas City residents use public transport, $23 \%$ of those - personal motorized transport systems and $17 \%$ walk or ride bicycles during rush hours.

Up to now, Kaunas City municipality has not designed any model for a transport system, and long-term connections have been selected on the basis of experience, engineering intuition and taking into account decisions made at the political level. The construction of a four-stage model for a personal motorized transport system and the evaluation of transport system development included the following tasks:

- a database describing the street network graph and land use model (distribution of population and workplaces) was designed;

- according to the conducted survey, the function $f\left(c_{i j}\right)$ of travel price was set and the coefficients of the function were determined using regression analysis; finally, on the basis of the above introduced figures, a model for travel demand was produced; 
- the coefficients of volume delay functions were established calibrating the model and applying the approximation method;

- the simulation of the motorized personal transport system was performed with reference to the application of optimization algorithms; the created model was used for evaluating the benefits of all solutions provided in the Kaunas City Master Plan up to 2023 and for identifying transport flows.

Model calibration requires the analysis of its parameters so that the results of the model should reflect reality in the most appropriate way. The quality of the model is described by the well-known coefficient of determination calculated according to the below presented formula:

$$
R^{2}=\frac{\sum_{i=1}^{n}\left(y_{m i}-\bar{y}\right)^{2}}{\sum_{i=1}^{n}\left(y_{i}-\bar{y}\right)^{2}},
$$

where: $y_{i}$ - observed values; $y_{m i}$ - simulated values; $\bar{y}$ average of the observed values.

$R^{2}=1$ means that the simulated values perfectly match the observed values. The more the coefficient of determination is closer to zero, the more predicted values differ from the observed ones.

The accuracy of the model is also defined by Relative Root Mean Squared Error (RMSE) indicating how much simulated values are different from the observed values:

$$
R M S E=\frac{\sqrt{\frac{1}{n} \cdot \sum_{i=1}^{n}\left(y_{i}-y_{m i}\right)^{2}}}{\frac{1}{n} \cdot \sum_{i=1}^{n} y_{i}} .
$$

The calibration of models for traffic flow includes a comparison of the observed and simulated traffic flow values. Data on the observed transport flows during the evening rush hour were used for calibrating the model for traffic flow. PTV VISUM software package draws a chart showing a linear regression curve between the simulated and observed values arranged in the coordinate plane (Figure 1). Calibration is focused on adjusting the parameters of the model in order the simulated values should be as far as possibly similar to those identified during observation, and the regression curve should be inclined at an angle of $45^{\circ}$.

The provided chart shows a comparison of $254 \mathrm{ob}-$ served and simulated traffic intensity values. The coefficient of determination is equal to 0.77 and indicates the reliability of the model. Relative RMSE is equal to $31 \%$.

Model calibration aims for the average duration of a single trip in the model thus matching the values found conducting the survey. With reference to the data received from the Kaunas City Master Plan in the course of the survey carried out at the stage of the present state analysis, the average duration of a single trip takes $25 \mathrm{~min}$, whereas the average duration of simulated travels counts $22 \mathrm{~min}$. Thus, time for the simulated travel is $12 \%$ less than that for the actual one.

The total travel time of motorized personal transport system users in the network is equal to 16900 Vehicle Hours Travelled (VHT) and the distance makes 459000 Vehicle Kilometres Travelled (VKT) under an average speed of $27.1 \mathrm{~km} / \mathrm{h}$. The cartogram of the current transport flows is shown in Figure 2.

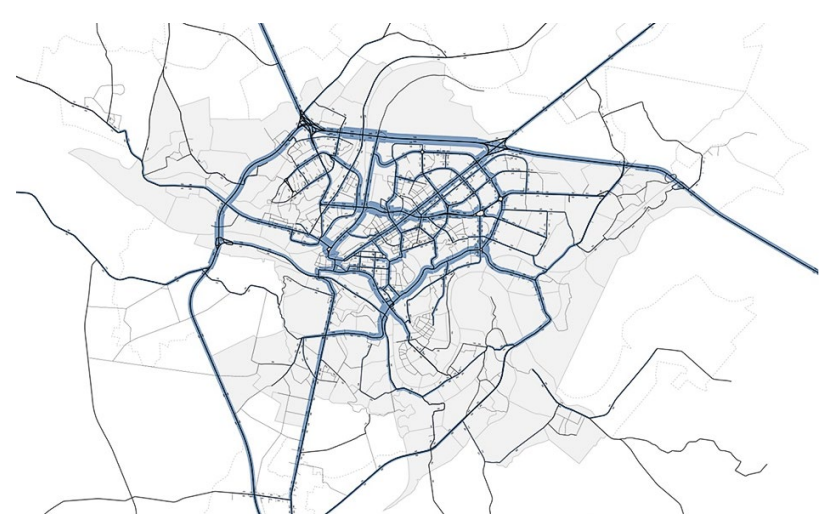

Figure 2. The cartogram of the current transport flows in Kaunas City

\section{Transport infrastructure development in Kaunas City until 2023}

The long-term Kaunas City transport system was designed in the city's Master Plan approved by the municipal council in April 2014 (Kauno miesto savivaldybe 2014). The

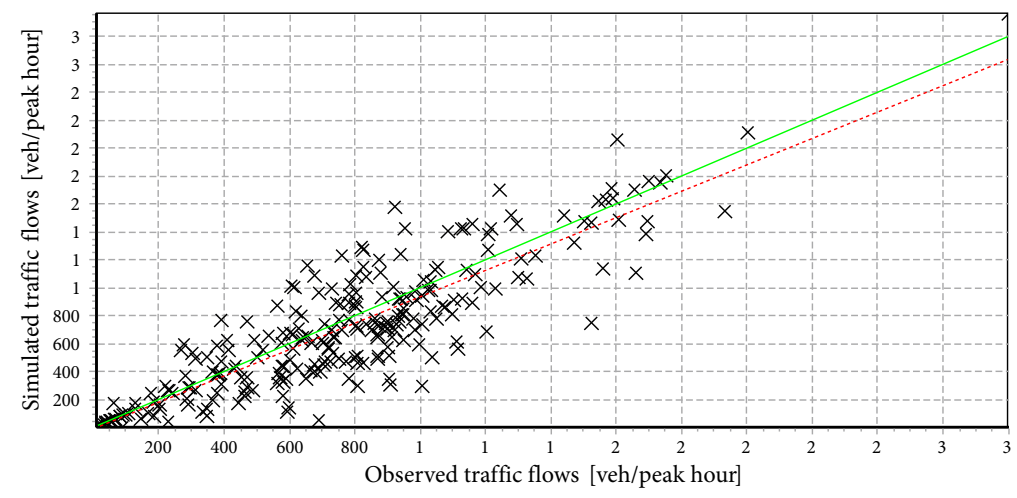

Figure 1. Assignment analysis 
concept of the Master Plan outlined a vision of how the transport system should look like from a quantitative point of view at the end of developing it. The created vision is presented in Figure 3 below.

The concept of the Master Plan provides the following basic development guidelines:

- the completion of the system for fast highways (category A);

- the completion of developing the system for the main and side streets (categories B and C);

- decreasing transport flows in the central part of the city (Old Town and Naujamiestis).

Currently, the system for fast-traffic streets in Kaunas City is implemented on the basis of trunk roads. After building the south-eastern bypass around Kaunas, the system of trunk roads should be mainly completed. The primary purpose of the network of the main and side streets (categories B and C) is to ensure links among functional zones, regions, district centres, major transport stations, to form links with trunk roads, the main public transport lines and to serve longer internal transport links in the city. The network has been established so as to form an annular-radial structure. The main ring road around the city centre is suggested to be formed from exclusively the network of category B streets thus ensuring its higher bandwidth and transportation speed.

The Old Town as a cultural heritage site, a gathering place for city residents and a part of the city image, should not be overloaded with transport flows that cause negative consequences. The principal direction towards downtown development should involve environmental humanisation thus reducing the technical parameters of excessively large streets and better adapting river embankments to the needs of the population.

This long-term vision will require significant investment in the final achievement of the specified goals. The Master Plan of Kaunas City provides solutions for the period of 2013-2023 and specifies political priorities to the

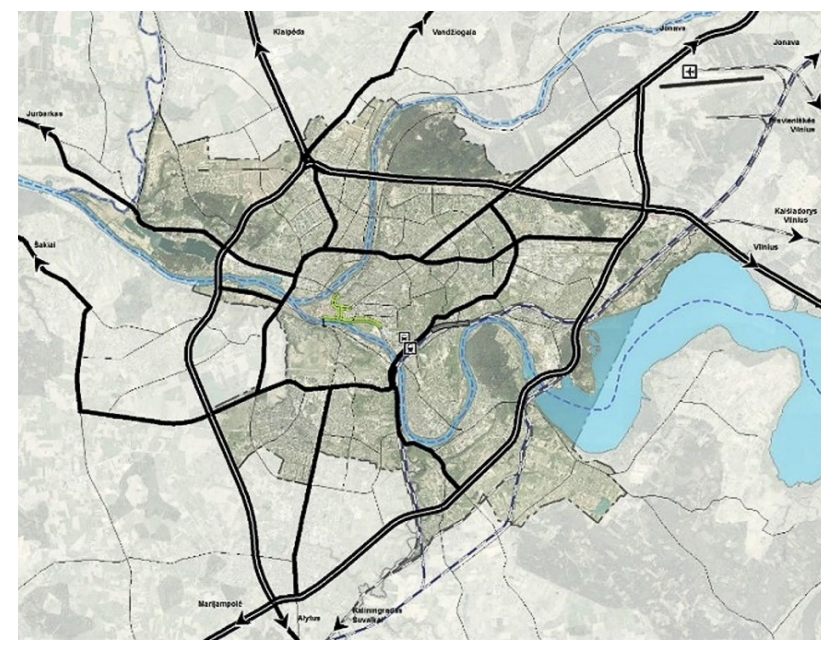

Figure 3. A concept of developing transport infrastructure in Kaunas City (Kauno miesto savivaldybe 2014) construction of new links and renovation of the existing ones. However, the Master Plan does not bring a wellgrounded and justified sequence to such solutions.

The first priority allows for eight solutions, the most important four of which cover

- Panemunè Bridge reconstruction;

- the construction of the south-eastern bypass;

- an extension of Europos Ave up to Highway A5 (Baltijos Str.);

- an extension of S. Žukausko Str. up to Highway A1 (Islandijos Rd.).

The second priority included eight solutions, and the third one comprised nine. The paper is aimed at reassessing and justifying solutions to the Master Plan thus ensuring that those giving the highest benefits will be reached first.

\section{Assessing the efficiency of developing the motorized personal transport system}

Each simulated scenario consists of the current state network supplemented with one or more Master Plan's solutions some of which are interdependent and can only be embodied together. For instance, the implementation of the South-Eastern bypass requires the employment of adjacent connections and streets falling in a lower category. The construction of the bypass will have to be accompanied by building the extension of Chemijos Ave, Biruliškių Str. and Didžiosios Str. As a result, this group of solutions is aggregated and simulated as a single scenario.

In order to assess the efficiency of different scenarios, two parameters must be set: preliminary costs and benefits created by implementing each of the scenarios. The benefits must be expressed in a certain monetary value, since only in the case of making the units of different parameters uniform will allow calculating the dimensionless ratio.

The preliminary cost of each scenario is calculated according to comparable economic indicators for unit prices of building construction and provided by UAB Sistela in March 2013. Estimation covered building new and renovating the existing streets as well as erecting new bridges, viaducts and overpasses.

The tasks involved detailed calculations of investments, and the benefits of each scenario were determined by simulating and assessing time savings and VOCs. Calculations do not cover the assessment of traffic accident savings and reduced environmental pollution. Therefore, the actual benefits of implementing projects are slightly higher, and the scope of the carried out analysis can be extended.

Hence, 20 separate scenarios for the personal motorized transport network in Kaunas City were simulated using the transport demand matrix dated to 2013 for the evening rush hour. The suggested cartogram of the forecasted transport flows shows the implementation of all 20 alternatives and is presented in Figure 4. 


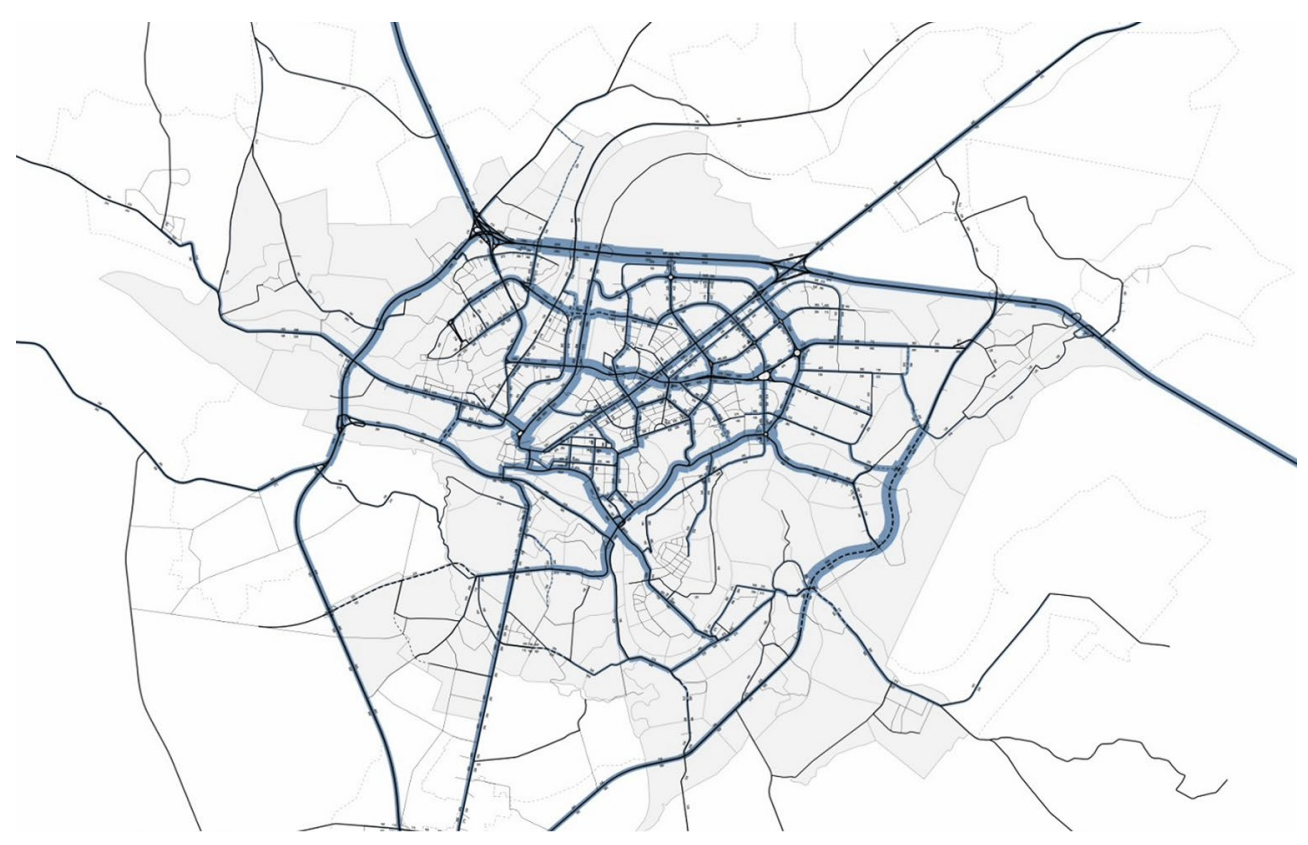

Figure 4. The cartogram of the forecasted transport flows in Kaunas City

The simulation process established VHT and VKT parameters of the whole simulated system at the evening rush hour time thus calculating the average travel speed of network users. In addition, with respect to the current state of the network, the savings of each of these parameters have been defined.

Finally, savings are expressed in accordance with the methodology and time costs provided in the Road Investment Manual and tariffs on VOC's set in 2013 (LAKD 2015).

Table shows a summary of separate scenarios for the motorized transport network. Considering every scenario, the ratio of annual savings has been calculated. The higher first year savings and investment ratio point to more useful scenarios. In the cases when the ratio is higher than one, it should be claimed that investment excessing benefits can be expected following the first year after implementing the scenario. Žeimenos and Studentų Str. are the scenarios the first year benefits of which exceed the expected investment (considering only time and VOC savings). In terms of costs, these scenarios are cheap enough and can be disposed among the first ones. S. Žukausko Str. appears third in the row. Baltu Ave Bridge is expensive to build, although its benefits are substantial. Therefore, it is placed in the fourth position. The implementation of the South-Eastern bypass will require the investment of more than 60 million euros, and the received benefits can reach about 8 million annually. Hence, this scenario takes the tenth position.

The greatest benefits will be produced by the realization of connections that will serve the most densely inhabited zones and reduce time and VOCs in these areas.

Considering the fact that the Kaunas City Master Plan put forward eight first priority scenarios (marked green in Table), eight second priority scenarios (marked blue in
Table) and nine third priority scenarios (marked yellow in Table), the most advantageous scenario in the Master Plan was intended to be implemented as the third priority. Meanwhile, taking into account benefits, the second scenario was provided only the second priority. This indicates that priorities, engineering intuition and experience-based decisions are not always the most useful and cost-favourable factors in decision-making.

The prepared model helped with determining the benefits of the proposed scenarios and assisted in assessing traffic flows. Therefore, with reference to the results of this paper, planners and designers may develop projects on adequate transport systems.

\section{Conclusions and recommendations}

Urban sustainability comprises complex interrelations between socio-political, environmental and economic subsystems. Consequently, it is crucial to find reasonable technological solutions to a number of problems encountered in these areas. The main idea validated by this study suggests that a deeper understanding of transport planning processes is important for Lithuanian circumstances and leads to new practical applications of urban planning issues when striving for more sustainable urban development.

The designed model for the transport system in Kaunas City focuses on the prioritization of transport system solutions provided in the Kaunas City Master Plan (cathegory A) of these solutions are not self-contained and can be embodied only together. To produce and calibrate a reliable model, evening rush hour flows appearing in the most important transport corridors and crossroads have been investigated. 
Table. Assessment results of scenarios

\begin{tabular}{|c|c|c|c|c|c|}
\hline $\begin{array}{l}\text { No of the } \\
\text { calculated } \\
\text { priority of } \\
\text { the scenario }\end{array}$ & $\begin{array}{c}\text { No of the } \\
\text { scenario } \\
\text { according to } \\
\text { the Master Plan }\end{array}$ & Street (category) & $\begin{array}{l}\text { Investment, } \\
\text { [thousand } \\
\text { EUR] }\end{array}$ & $\begin{array}{l}\text { Time and VOC } \\
\text { savings, [thousand } \\
\text { EUR/year] }\end{array}$ & $\begin{array}{l}\text { First year } \\
\text { savings and } \\
\text { investment } \\
\text { ratio }\end{array}$ \\
\hline 1 & 24 & Žeimenos Str. (C1) & 1014 & 1480 & 1.46 \\
\hline 2 & 9 & Studentų Str. (C2) & 166 & 173 & 1.04 \\
\hline 3 & 4 & S. Žukausko Str. (C1) & 3211 & 2051 & 0.64 \\
\hline 4 & 12 & Baltų Ave Bridge with connecting streets (C1/C2) & 12586 & 4340 & 0.34 \\
\hline 5 & 23 & $\begin{array}{l}\text { Connection between Elektrènų Str. } \\
\text { and Taikos Ave (C2) }\end{array}$ & 514 & 143 & 0.28 \\
\hline 6 & 6 & Linkuvos Str./Žemaičių Rd. (B1) & 1938 & 536 & 0.28 \\
\hline 7 & 18. & Jiesios Rd. (B2) & 1292 & 333 & 0.26 \\
\hline 8 & 1 & Panemunès Bridge $(\mathrm{C} 1)$ & 16463 & 3837 & 0.23 \\
\hline 9 & 15 & Lakūnų Rd./E. Žilibero Str. (C1/C2) & 1491 & 276 & 0.19 \\
\hline 10 & $2,8,21$ and 16 & $\begin{array}{l}\text { South-Eastern bypass (A2)/Chemijos Ave (C1)/ } \\
\text { Biruliškių Str. (C1)/Didžioji Str. (C1) }\end{array}$ & 59545 & 8034 & 0.13 \\
\hline 11 & 22 & Vaidoto Str. (C1) & 1109 & 108 & 0.10 \\
\hline 12 & 10 & H and O. Minkovskių Str. (B1) & 2068 & 197 & 0.10 \\
\hline 13 & 17 & Piliakalnio Str. (B2) & 3360 & 319 & 0.09 \\
\hline 14 & 3 & Europos Ave. (B1) & 8353 & 388 & 0.05 \\
\hline 15 & 11 & Brastos Str. (Kèdainių Bridge) (B1) & 34231 & 1375 & 0.04 \\
\hline 16 & 19 & Plytinès Str./Rokų Str. (B2) & 2929 & 106 & 0.04 \\
\hline 17 & 14 & Šeštokų Str./Alyvų Str. (B2) & 2972 & 105 & 0.04 \\
\hline 18 & 13 & Technikumo Str./Bartelių Str./Juodelynès Str. (C2) & 2044 & 43 & 0.02 \\
\hline 19 & 25 & Užnerio Str./Bangos Str. (C2) & 964 & 4 & 0.00 \\
\hline 20 & 20 & J. Grušo Str./Jotvingių Str. (C1) & 5115 & -88 & -0.02 \\
\hline \multicolumn{6}{|l|}{ Explanations: } \\
\hline & \multicolumn{5}{|c|}{ - first priority scenarios according to the city's Master Plan; } \\
\hline & \multicolumn{5}{|c|}{ - second priority scenarios according to the city's Master Plan; } \\
\hline & \multicolumn{5}{|c|}{ - third priority scenarios according to the city's Master Plan. } \\
\hline
\end{tabular}

Preliminary investments and benefits for each of the implemented scenarios have been established. Investment values have been calculated using the prices of construction units introduced by UAB Sistela. The benefits have been estimated by simulating each scenario and determining VOC economy of VHT and VKT with respect to the model for the current state. To compare investment and benefits, the obtained results have been expressed in terms of a certain monetary value.

The case study indicates that the extension of Žeimenos Str. has been found to achieve the best ratio of benefits to investment (third priority in the Master Plan) while benefits should exceed investment in the first year. The extension of Studentu Str. (second priority in the Master Plan), S. Žukausko Str. (first priority in the Master Plan) and the bridge with connecting streets on Baltų Ave (second pri- ority in the Master Plan) continue the list of calculated priorities.

The obtained results confirm that reliance on political decisions, engineering intuition or other unspecified ways is not enough as it is necessary to include independent decision-making techniques. Cost-benefit analysis, including simulation, is one of the ways that can propose reasonable results ensuring the needs of society and the rational use of funds. The authors suggest that the initial prioritization of scenarios should be based on the first year savings and an indicator for investment ratio.

All in all, the findings of the study demonstrate that political decisions are not always correct in making complex decisions, which leads to the irrational use of resources that develop objects important to the public. The implemented macro-simulation of motorized transport 
flows in the territory of Kaunas City is a basis for further improvement, for simulating the organization of public transport traffic in Kaunas, for assessing environmental impact, further joint modernization and developing the urban transport infrastructure and network of public transport routes.

\section{References}

Barfod, M. B.; Salling, K. B.; Leleur, S. 2011. Composite decision support by combining cost-benefit and multi-criteria decision analysis, Decision Support Systems 51(1): 167-175. https://doi.org/10.1016/j.dss.2010.12.005

Beria, P.; Maltese, I.; Mariotti, I. 2012. Multicriteria versus cost benefit analysis: a comparative perspective in the assessment of sustainable mobility, European Transport Research Review 4(3): 137-152. https://doi.org/10.1007/s12544-012-0074-9

Grigonis, V.; Burinskienè, M.; Paliulis, G.; UšpalytèVitkūnienė, R.; Dumbliauskas, V.; Barauskas, A. 2014. Modelling a passenger car system based on the principles of sustainable mobility in Vilnius City, Transport 29(3): 334-341. https://doi.org/10.3846/16484142.2014.953998

Grigonis, V.; Paliulis, G. M. 2007. Modelling the transport flows in Marijampole (Lithuania), The Baltic Journal of Road and Bridge Engineering 2(1): 29-37.

Griškevičiūtè-Gečienè, A. 2010. The evaluation of investment projects within the territory of development, Transport 25(2): 203-214. https://doi.org/10.3846/transport.2010.25

Gühnemann, A.; Laird, J. J.; Pearman, A. D. 2012. Combining cost-benefit and multi-criteria analysis to prioritise a national road infrastructure programme, Transport Policy 23: 15-24. https://doi.org/10.1016/j.tranpol.2012.05.005

Haque, M. M.; Chin, H. C.; Debnath, A. K. 2013. Sustainable, safe, smart - three key elements of Singapore's evolving transport policies, Transport Policy 27: 20-31. https://doi.org/10.1016/j.tranpol.2012.11.017

Hassan, A. M.; Lee, H. 2015a. The paradox of the sustainable city: definitions and examples, Environment, Development and Sustainability 17(6): 1267-1285. https://doi.org/10.1007/s10668-014-9604-Z

Hassan, A. M.; Lee, H. 2015b. Toward the sustainable development of urban areas: an overview of global trends in trials and policies, Land Use Policy 48: 199-212. https://doi.org/10.1016/j.landusepol.2015.04.029

Hickman, R.; Hall, P.; Banister, D. 2013. Planning more for sustainable mobility, Journal of Transport Geography 33: 210219. https://doi.org/10.1016/j.jtrangeo.2013.07.004

Hüging, H.; Glensor, K.; Lah, O. 2014. Need for a holistic assessment of urban mobility measures - review of existing methods and design of a simplified approach, Transportation Research Procedia 4: 3-13. https://doi.org/10.1016/j.trpro.2014.11.001

Kauno miesto savivaldybe். 2014. Kauno miesto savivaldybès teritorijos bendrasis planas 2013-2023 m. Available from Internet: http://www.kaunas.lt/urbanistika/bendrasis-planavimas/ kauno-miesto-savivaldybes-teritorijos-bendrasis-planas2013-2023-m (in Lithuanian).

Kerali, H. 2003. Economic appraisal of road projects in countries with developing and transition economies, Transport Reviews 23(3): 249-262. https://doi.org/10.1080/0144164032000068920
Kim, S.; Rowe, P. G. 2013. Are master plans effective in limiting development in China's disaster-prone areas?, Landscape and Urban Planning 111: 79-90.

https://doi.org/10.1016/j.landurbplan.2012.12.001

Kumarage, A. S.; Weerawardana, J. 2013. System cost-based multi-criteria analysis for urban transport solutions, International Journal of Urban Sciences 17(2): 212-225. https://doi.org/10.1080/12265934.2013.776285

LAKD. 2015. Automobiliu keliu investiciju vadovas. Lietuvos automobilių kelių direkcija (LAKD) prie Susisiekimo Ministerijos 122 p. (in Lithuanian).

Martos, A.; Pacheco-Torres, R.; Ordóñez, J.; Jadraque-Gago, E. 2016. Towards successful environmental performance of sustainable cities: intervening sectors. A review, Renewable and Sustainable Energy Reviews 57: 479-495. https://doi.org/10.1016/j.rser.2015.12.095

Santos, A. S.; Ribeiro, S. K. 2015. The role of transport indicators to the improvement of local governance in Rio de Janeiro City: a contribution for the debate on sustainable future, Case Studies on Transport Policy 3(4): 415-420. https://doi.org/10.1016/j.cstp.2015.08.006

Tennøy, A.; Hansson, L.; Lissandrello, E.; Næss, P. 2016. How planners' use and non-use of expert knowledge affect the goal achievement potential of plans: experiences from strategic land-use and transport planning processes in three Scandinavian cities, Progress in Planning 109: 1-32. https://doi.org/10.1016/j.progress.2015.05.002

TRB. 2010. Highway Capacity Manual. 5th edition. Transportation Research Board (TRB), Washington, DC, US. 1650 p. 